\title{
Rancang Bangun Absensi Mahasiswa Berbasis Fingerprint Menggunakan Komunikasi Wireless
}

\author{
Mohamad Dimyati Ayatullah ${ }^{1 *}$, Enes Ariyanto Sandi ${ }^{2}$, Galih Hendra Wibowo ${ }^{3}$ \\ ${ }^{1,3}$ Jurusan Teknik Informatika, Politeknik Negeri Banyuwangi, Banyuwangi \\ ${ }^{2}$ Jurusan Teknik Sipil, Politeknik Negeri Banyuwangi, Banyuwangi \\ 1,2,3 Jln. Raya Jember Km 13, Kota Banyuwangi, 52142, Indonesia \\ email: ${ }^{1}$ dimyati@poliwangi.ac.id, ${ }^{2}$ enes.ariyanto@ poliwangi.ac.id, ${ }^{3}$ galih@poliwangi.ac.id
}

Copyright @2019, Politeknik Harapan Bersama, Tegal

\begin{abstract}
The teaching and learning process on campus is always supervised by paying attention to attendance. Some campuses use this attendance as a condition for taking the exam. However, the attendance system is still manual, which is by using a signature on the attendance sheet. This system has several weaknesses which include the occurrence of fraudulent attendance, difficulty in monitoring attendance, and data that cannot be presented quickly. The study proposes an attendance system using fingerprints connected to wireless networks that are already available on campus. Wireless networks are used as a medium of communication between attendance tools and database servers. The use of wireless networks aims to facilitate equipment used in classrooms during the lecture process. Attendance tool designed on a single Raspberry Pi computer board that is equipped with fingerprint sensors, power banks and LCD screens. While wireless LAN devices are integrated in the Raspberry Pi boar. The attendance system begins with an enroll process to save the lecturer and student fingerprint templates. Each template is given an ID to be stored on the database server using TCP wireless and protocol networks. The enroll process observations require an average time of 4 seconds which consists of: transmission time and time identification of fingerprint characteristics to the creation of fingerprint templates. The attendance process in lecture activities begins with the absence of lecturers and is followed by students. The average time needed to do attendance is 4 seconds. During the data attendance process can transmit between the attendance device (client) and server. Through a fingerprint-based attendance device based on the available wireless network infrastructure in the campus, it can improve the efficiency of attendance monitoring in real time.
\end{abstract}

Abstrak - Proses belajar mengajar di kampus selalu diawasi dengan cara memperhatikan absensi. Beberapa kampus menggunakan absensi ini sebagai syarat untuk mengikuti ujian. Namun, sistem absensi yang berlangsung hingga saat ini masih manual, yakni dengan menggunakan tanda tangan pada lembar absensi. Sistem ini mempunyai beberapa kelemahan yang diantaranya adalah terjadinya kecurangan, sulit melakukan pengawasan, dan data tidak dapat disajikan secara cepat. Penelitian mengusulkan sistem absensi menggunakan sidik jari yang dihubungkan dengan jaringan wireless yang sudah tersedia di kampus. Jaringan wireless digunakan sebagai media komunikasi antara alat absensi dengan database server. Pemanfaatan jaringan wireless bertujuan untuk memudahkan peralatan digunakan pada ruang kelas pada saat proses

*) penulis korespondensi: Mohamad Dimyati Ayatullah

Email: dimyati@poliwangi.ac.id perkuliahan. alat absensi dirancang pada single board computer raspberry pi yang dilengkapi dengan sensor fingerprint, power bank dan layar LCD. Sedankan perangkat wireless LAN terintegrasi pada boar raspberry $\mathbf{P i}$. Sistem absensi diawali dengan melakukan proses enroll untuk menyimpan template sidik jari dosen dan mahasiswa. Setiap template diberi ID untuk disimpan pada database server menggunakan jaringan wireless dan protocol TCP. Hasil pengamatan proses enroll membutuhkan waktu rata-rata 4 detik yang terdiri dari: waktu transmisi dan waktu identifikasi karakteristik sidik jari hingga pembuatan template sidik jari. Proses absensi saat perkuliahan diawali dengan dosen dan dikuti mahasiswa. Rata-rata waktu yang dibutuhkan untuk melakukan absensi 4 detik. Selama proses absensi data dapat transmisikan antara alat absensi (client) dan server. Melalui Alat absensi berbasis fingerprint dengan basis infastruktur jaringan wireless yang tersedia dikampus mampu meningkatkan efisiensi pengawasan kehadiran secara real time.

Kata Kunci - Sistem Absensi, Wireless, Fingerprint, Raspberry Pi.

\section{PENDAHULUAN}

Absensi merupakan sebuah metode yang digunakan untuk memantau kehadiran seseorang pada suatu kegiatan. Perkuliahan merupakan sebuah proses belajar mengajar yang melibatkan mahasiswa dan dosen pada suatu ruang dan waktu. Salah satu indikator keberhasilan perkuliahan adalah tingkat kehadiran mahasiswa pada waktu jam kuliah. Beberapa kampus membuat aturan batas minimal tingkat kehadiran mahasiswa dalam perkuliahan. Hal ini digunakan sebagai syarat untuk mengikuti ujian pada tengah atau akhir semester [2].

Pendataan absensi saat ini menggunakan manual, yaitu dengan cara melakukan tanda tangan pada daftar nama yang sudah disediakan oleh akademik. Mahasiswa memungkinkan untuk menadantangani lebih dari satu nama pada saat mengikuti perkuliahan. Mahasiswa yang tidak hadir dapat minta bantuan salah satu mahasiswa yang hadir dalam perkuliahan untuk melakukan absensi. Absensi manual dapat menimbulkan kecurangan yang dilakukan mahasiswa $[3,4]$. Disamping itu, pengawasan absensi mahasiswa secara manual membutuhkan perhatian khusus. Selain itu, pendataan absensi manual membebani tenaga administrasi untuk memasukan data ke komputer. 
Sidik jari adalah salah satu bentuk bidang biometrik yang digunakan untuk melakukan identifikasi sesorang dan mempunyai karekteristik yang unik. Otentikasi menggunakan sidik jari banyak diterapakan pada berbagai bidang. Pada awalnya penerapan sidik jari mengunakan tinta yang dibubuhkan pada bagian permukaan jari dan menempelkan ke sebuah kertas[5]. Penerapan metode demikian banyak digunakan pada kepolisian atau masyarakat sebagai bukti pembayaran yang bisa disebut dengan cap jempol. Perkembangan teknologi saat ini sudah mampu untuk menghasilkan sebuah data digital dari sidik jari.

Penelitian ini mengusulkan sebuah prototipe alat absensi mahasiswa menggunakan fingerprint yang terhubung dengan jaringan wireless lokal kampus. Alat ini bersifat portable, sehingga mudah dibawa ke berbagai tempat perkuliahan. Penggunaan jaringan wireless digunakan sebagai media komunikasi alat dengan database server.

\section{PENELITIAN YANG TERKAIT}

Beberapa penelitian yang berkiatan dengan pengembangan sistem absensi telah dilakukan, diantaranya: otomatisasi system absensi menggunakan module fingerprint [3]. Aplikasi dibangun menggunakan perangkat ARM7 yang dilengkapai LCD dan sensor fingerprint untuk mengambil data sidik jari. ARM7 dikoneksi dengan sebuah PC untuk menyimpan data dengan dilengkapi dengan aplikasi yang dibangun menggunakan bahasa java. Perangkat ini dibangun dengan tujuan untuk menggantikan sistem absensi tradisional. Sensor fingerprint mengambil gambar sidik jari yang kemudian diextrasi menggunakan fitur yang ada pada fingerprint. Hasil extrasi berupa template yang tersimpan dalam database sensor fingerprint sebagai tanda kehadiran.

Penelitian lain juga sudah dilakukan dan menghasilkan sebuh publikasi dengan judul "Integrasi Fingerprint System Dengan Real Time Absensi Dosen Berbasis Web" telah menyajikan pembuatan aplikasi absensi dosen di perguruan tinggi STMIK Pontianak berbasis web. Absensi menggunakan fingerprint dapat memberikan informasi yang real time bagi manajemen perguran tinggi. Intergrasi sistem fingerprint dengan aplikasi yang dibangun menggunakan web dapat meberikan informasi cepat dan akuran tentang keberadaan dosen di kampus. Keluar dan masuk dosen dapat identifikasi setiap kali dosen melakukan pendeteksian sidik jari. Dalam paper tersebut penulis juga menjelaskan pengembangan dari sistem dengan menambahkan teknologi SMS Gateway untuk memberikan informasi kapada semua dosen berkaitan dengan jadwal mengajar[4].

Sebuah penelitian yang bertema sistem absensi untuk mahasiswa menggunakan biometric dan GPS[8]. Tujuan pengembangan sistem untuk mengembangkan sistem embedded yang diterapakan pada absensi. Modul dikembangan menggunakan mikrokontroller dan sensor fingerprint. GPS digunakan untuk medeteksi keberadaan mahasiswa yang dikirim ke orang tua menggunakan jaringan GSM. Sebuah aplikasi pengolahan data dikembangan menggunakan bahasa $\mathrm{C \#}$ dan framework .NET dengan database SQL Server 2005. Modul dilengkapi dengan kamera yang digunakan untuk mengambil gambar mahasiswa saat melakukan absensi. Gambar tersebut digunakan untuk mengidentifikasi mahasiswa dalam penelitian lebih lanjut.
Sistem absensi dengan fingerprint menggunakan wireless dengan kontrol menggunakan arduino yang dihubungkan dengan sensor fingerprint tipe R305[6]. Perangkat wireless yang digunakan untuk mengirimkan data ke komputer menggunakan xbee. Perangkat xbee yang digunakan sebanyak 2 buah untuk pengirim dan penerima. Pengirim data dihubungkan dengan arduino dan penerima data dikoneksikan dengan PC. Identifikasi user menggunakan ID yang diberikan fingerprint dan disimpan dalam PC. Penulis juga menjelaskan pengembang dari sistem yang diusulkan dengan membangun aplikasi online menggunakan JST dan HTML. Pengembangan sistem tersebut bertujuan untuk meningkatkan pengamanan diberbagai tempat.

Hal yang sama juga dilakukan Yongqiang Zhang dalam sebuah penelitian sistem managemen absensi menggunakan wireless dan fingerprint [7]. Data disimpan dalam sebuah database yang berada dalam sebuah PC. Modul $R F$ wireless dan fingerprint terintegrasi dengan microcontroller AT89C5122 sebagi sistem kontrol. Penelitian ini menjelaskan perpaduan antara fingerprint dan wireless dapat mengurangi pemalsuan kehadiran dan mengurangi tingkat kesulitan dalam penempatan perangkat absensi apabila menggunakan kabel sebagai konektor ke PC.

Pada penelitian ini diusulkan sebuah prototipe sistem absensi mahasiswa berbasis fingerprint menggunakan koneksi jaringan wireless. Sistem dibangun menggunakan mini Komputer, raspberry $\mathrm{Pi} 3$, yang dilengkapi dengan radio wireless LAN 802.11. Apliksi dibangun menggunakan bahasa Python. Pengambilan data fingerprint menggunakan sensor fingerprint tipe R305 mengunakan serial sebagai komunikasi sensor dengan mini komputer.

\section{METODE PENELITIAN}

\section{A. Desain Hardware}

Desain rancangan prototype absensi menggunakan fingerprint terlihat pada gambar 1. Pada sistem absensi yang diusulkan terdiri dari beberapa bagian, yaitu: perangkat fingerprint seabagai alat untuk mengambil sidik jari, jaringan wifi sebagai perangkat trasmisi data ke server dan database server sebagai pusat data. Perangkat fingerprint terdiri dari: powerbank untuk sumber energi, sensor fingerprint untuk pengambil sidik jari, LCD untuk menampilkan aplikasi absensi, keyboard untuk proses input data dan raspberry pi untuk kontrol sistem.

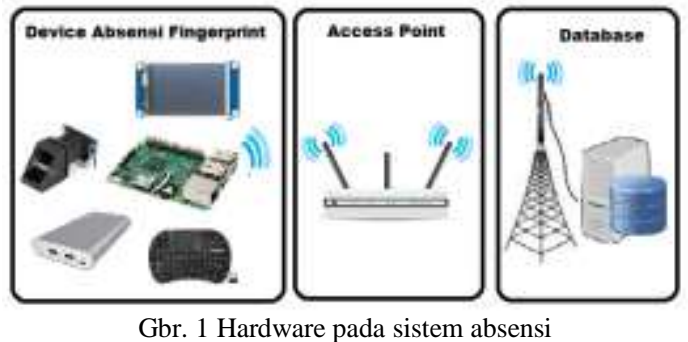

Desain sistem absensi mahasiswa terlihat pada gambar 2 . Perangkat absensi dikoneksi dengan jaringan wifi lokal untuk mendapat mengakses database yang berada di server lokal. Selanjutnya dilakukan proses enroll untuk mendapatkan template sidik jari tiap user. Tamplate disimpan pada storage yang disediakan fingerprint scanner. Tiap template diberi ID 
yang disimpan dalam database dan fingerprint scanner. ID template sebagai kunci dalam pencarian dalam database.

Proses absensi diawali dengan mengkoneksikan perangkat absensi dengan WIFI jaringan lokal. Selanjutnya dilakukan absensi dengan mencocokan sidik jari user ke fingerprint scanne, proses ini menghasilkan ID template yang dapat digunakan untuk pencarian data pada database.

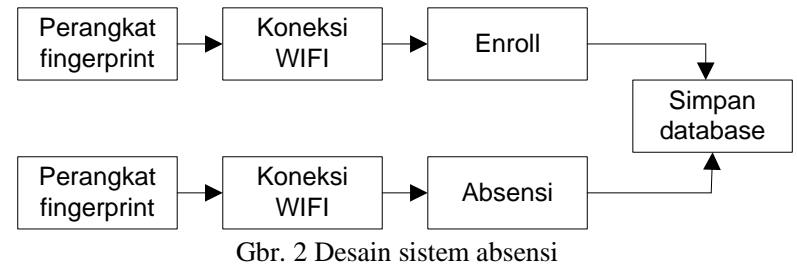

Berikut merupakan penjelasan beberapa peralatan yang digunakan dalam pembuatan prototype absensi fingerprint adalah:

1) Raspberry Pi

Raspberry Pi merupakan single board computer yang didukung oleh sistem operasi linux dan banyak digunakan oleh pengembang embedded system [9]. Raspberry Pi dikembangkan Raspberry Pi Foundation UK [1]. Raspberry Pi-3 Model B mempunyai kecepatan CPU $700 \mathrm{MHz}$ sampai $1.2 \mathrm{GHz}$ dengan memory $256 \mathrm{MB}$ sampai $1 \mathrm{~GB}$. Port USB disediakan sebanyak 4 port untuk mendukung penambahan perangkat lain dan 40 ping GPIO yang dapat digunakan sebagai suplai tegangan, PWM, SPI, I2C, serial atau input output. Port HDMI sebagai connector ke layar monitor. Raspberry Pi-3 Model B menyediakan perangkat koneksi jaringan menggunakan port Ethernet dan Wireless LAN $[10,11,13]$.

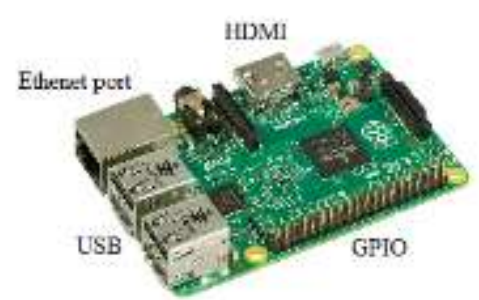

Gbr. 3 Perangkat Raspberry Pi 3

Wireless LAN $2.4 \mathrm{GHz} 802.11 \mathrm{n}$ tersedia dalam chip board BCM43438. IEEE 802.11 adalah seperangkat standar IEEE yang mengatur metode transmisi menggunakan jaringan nirkabel. Standar IEEE 802.11 tersebut terdiri dari beberapa versi yaitu: versi 802.11a, 802.11b, 802.11g, 802.11n, dan 802.11ac. 802.11n merupakan gabungan dari standar 802.11a dan 802.11g mempunyai kemampuan peningkatan kecepatan $54 \mathrm{Mbit} / \mathrm{s}$ to $600 \mathrm{Mbit} / \mathrm{s}$, meningkatkan keamanan, dan meningkatkan throughput.

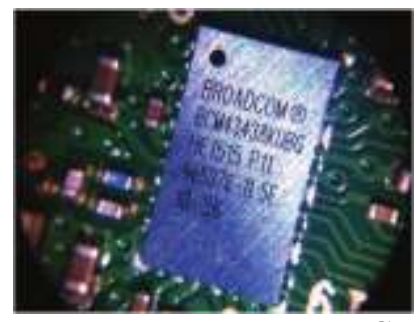

Gbr. 4 wireless LAN pada board chip BCM43438

\section{2) Sensor fingerprint}

Sensor fingerprint digunakan untuk mendeteksi pola sidik jari. Salah satu teknologi yang dikembangakan untuk mengambil sidik jari adalah menggunakan teknik Fiber Optic Plate (FOP) yang terdiri dari susunan fiber optic[5]. Jari yang diletakan pada bagian atas FOP guratan lapisan kulit jari yang menonjol memantulkan cahaya dari light, sedang bagian guratan yang cekung tidak. Pantulan cahaya tersebut diterima CCD/CMOS dan disimpan dalam bentuk template.

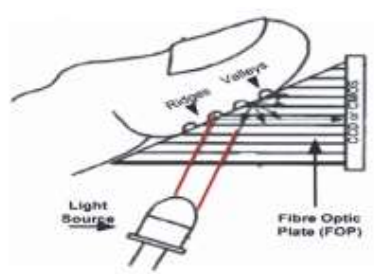

Gbr. 5 Sensor fingerprint berbasis fiber optic

Tipe sensor fingerprint yang digunakan pada penelitiaan ini ZFM 70. Specifikasi sensor antaravlain: suplai tegangan 3$7 \mathrm{~V}$, ukuran template $512 \mathrm{~KB}$, koneksi menggunakan UART, rata-rata waktu pencarian kurang 1 detik. Fingerprint scanner dikoneksikan ke Raspberry Pi mengunakan konektor USB UART dan dilakukan pengkodean menggunakan bahasa python. Fingerprint scanner diinisialisasi pada /dev/ttyUSB* dalam Raspberry Pi.

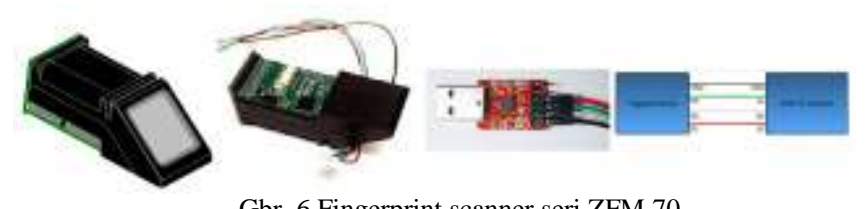

Gbr. 6 Fingerprint scanner seri ZFM 70

Proses pendaftaran sidik jari oleh sensor fingerprint disebut enroll. Fingerprint scanner mengidentifikasi dan menyimpan sidik jari dalam bentuk template di dalam storage yang ada pada fingerprint scanner[9]. Pada fingerprint scanner jenis ZFM 70 dapat menyimpan 1000 template sidik jari. Asumsi setiap orang yang catatatkan sidik jari pada fingerprint scanner sebanyak 1 sidik jari maka fingerprint scanner ZFM 70 dapat menyimpan data 1000 orang.

Peoses scanning pada tahapan enroll dilakukan 2 kali. Hasil scanning berupa image yang dirubah dalam character yang disimpan dalam buffer 1 dan buffer 2. Ke dua buffer dibandingkan, apabila mendapatkan kecocokan maka dibuat sebuah template dan ID sebagai identifikasi fingerprint. Template dan ID disimpan dalam storage sensor fingerprint. Database diperbarui dengan memasukan ID kedalam tabel pada database server.

Absensi dilakukan dengan mencocokan fingerprint yang sebelumnya sudah disimpan sensor fingerprint. Hasil proses pencocokan adalah ID yang digunakan untuk mencari data yang ada dalam tabel database. Setelah ditemukan dilakukan update database. 


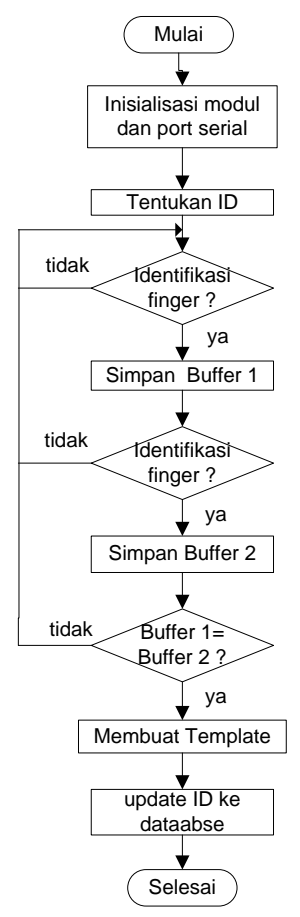

(a) proses Enroll

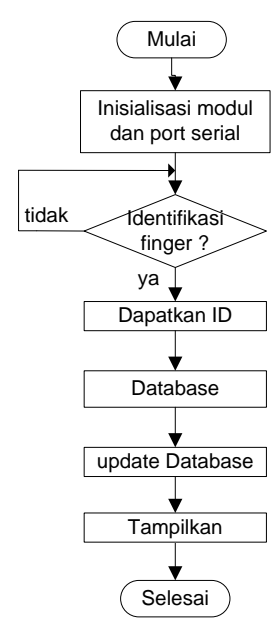

(b) proses absensi

Gbr. 7 Diagram alir proses enroll dan absesni

\section{B. Perancangan Database}

Database sebagai pusat penyimpanan data sebuah sistem informasi. Pada sistem absensi perangan database dilakukan dengan membuat diagram konteks dan Entity Relationship Diagram.

\section{1) Diagram Konteks}

Diagram Konteks sistem absensi mahasiswa digunakan untuk mengambarkan aliran data sebuah sistem informasi secara global. Entitas sistem adalah Dosen dan mahasiswa. Masukan sistem biodata, sidik jari, jadwal kuliah dan mata kuliah. Laporan sistem adalah pelaksanaan perkuliahan dan tingkat kehadiaran mahasiswa.

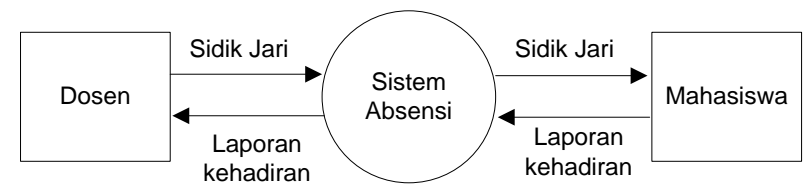

Gbr. 8 Diagram konteks sistem absensi mahasiswa

\section{2) Entity Relationship Diagram (ERD)}

ERD digunakan untuk mengambarkan pemodelan hubungan data dalam database pada sistem. ERD mempuyai 3 komponen simbul yaitu: entity, atribut dan Hubungan. Entity sistem absensi adalah dosen, mahasiswa, mata kuliah, kelas, kehadiran, program studi, kehadiran mahasiswa dan kehadiran dosen. Atribut dan hubungan masing-masing entity telihat pada gambar 9 .

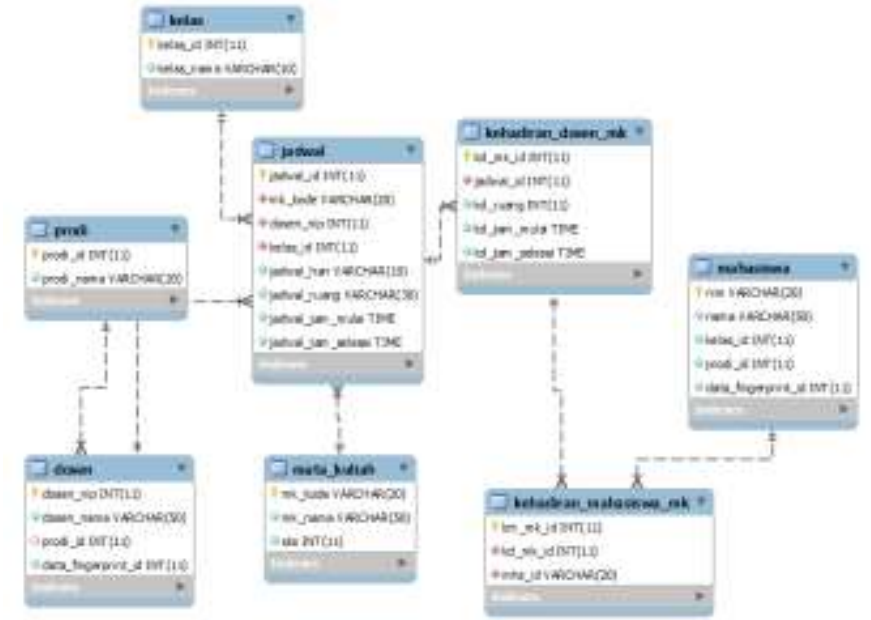

Gbr 9 ERD sistem absensi mahasiswa

IV. HASIL DAN PEMBAHASAN

Sistem absensi dibangun menggunakan bahasa python dan Raspbian versi stretch sebagai sistem operasi pada mini komputer Raspberry Pi 3. Database menggunakan MySQL yang install pada sebuah server. Koneksi antara alat absensi dan database server menggunakan jaringan wireless yang tersedia di kampus.

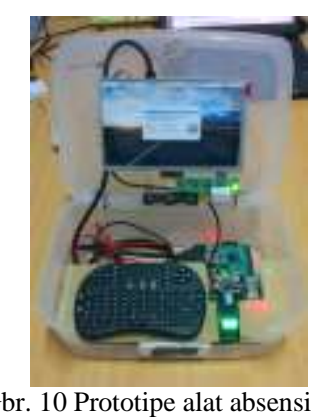

\section{1) Koneksi wireless $L A N$}

Komunikasi alat absensi dengan server menggunakan jaringan Wireless LAN. Alat absensi dilengkapi wireless LAN pada chip board BCM43438 mendapatkan IP address dari access point yang tersedia di wilayah kampus. Konfigurasi perangkat wireless dengan memodifikasi file letc/wpa_supplicant/wpa_supplicant.conf.

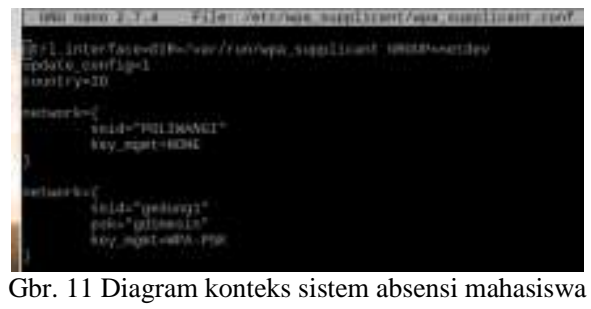

Pada gambar 11, wireless dihubungkan dengan access point dengan SSID poliwangi dan SSID gedung1. Perangkat dapat dihubungkan pada access point yang menggunakan enkripsi PSK. Pengunjian koneksi dapat dilakukan dengan ping IP address server. Kekuatan signal access point dapat dilihat menggunakan scanning jaringan wireless. Perintah iwlist wlan0 scan, menghasilkan informasi beberapa jaringan 
wireless yang dapat ditangkap dilengkapi dengan informasi level signal, seperti pada gambar 12 .

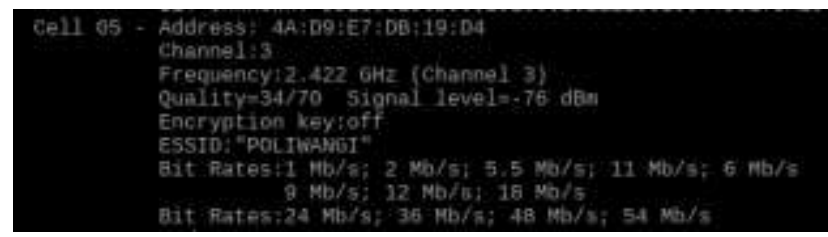

Gbr. 12 Signal lever access point poliwangi $-76 \mathrm{dBm}$

\section{2) Pendaftaran Sidik Jari}

Dosen dan mahasiswa melakukan proses pendaftaran atau enroll sidik jari pada fingerprint scanner. Proses pendaftaran diawali dengan memasukan nomor berupa NIK/NIP untuk dosen dan NIM untuk mahasiswa. Setelah data dosen atau mahasiswa diidentifikasi dalam database, dilanjutkan dengan pendaftaran sidik jari. Setiap sidik jari yang disimpan diberi nomor ID secara increment oleh fingerprint scanner. Nomor ID dikirim ke server untuk disimpan dalam database sebagai identifikasi dosen ataupun mahasiswa antara database dan fingerprint scanner.

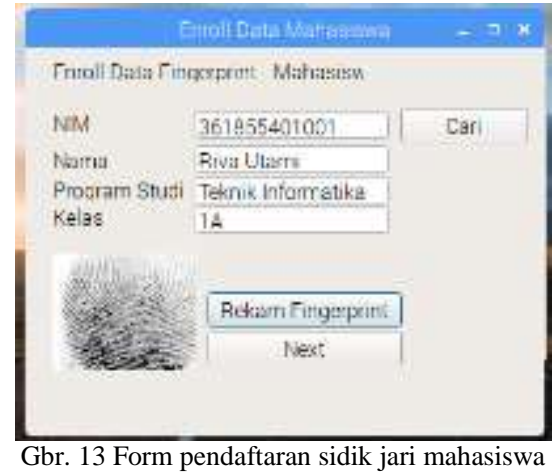

Proses trasmisi data antara alat absensi dan server diamati menggunakan aplikasi wireshark. Gambar 14 menampilkan hasil capture saat alat absensi melakukan komunikasi dengan server. Alat absensi sebagai client mengirimkan paket request query menggunakan port 41934 dan server merespon menggunakan port 3306 yang merupakan port database MySQL server. Transmisi menggunakan protocol TCP untuk menjamin data dapat diterima secara lengkap. Hasil pengujian menunjukan semua nomor ID yang dihasilkan dari proses pendaftaran sidik jari dapat tersimpan pada database server. Nomor ID digunakan untuk menghubungkan data absensi yang tersimpan di database dengan template sidik jari yang disimpan pada sensor fingerprint.

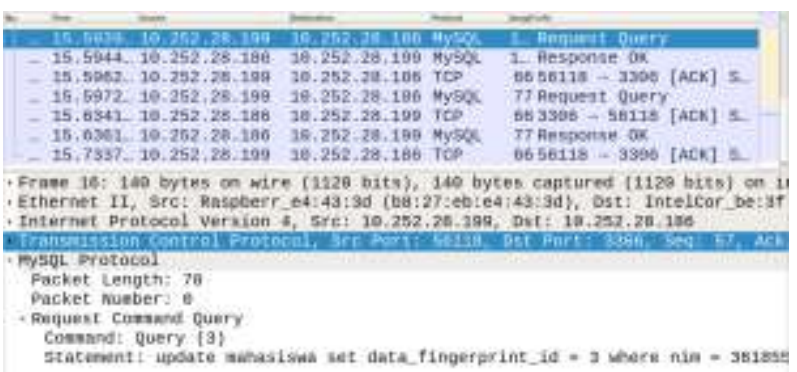

Gbr. 14 Data proses enroll ditraminsikan ke server
Waktu yang dibutuhkan proses pendaftaran sidik jari dipengaruhi oleh waktu transmisi data antara alat absensi dan server dan waktu identifikasi karakteristik sidik jari yang dilakukan oleh sensor fingerprint. Hasil pengujian terlihat pada tabel 1. Kemampuan sensor fingerprint melakukan identifikasi karakteristik sidik jari sampai dibuatkan template rata 4 detik. Sedangkan waktu yang dibutuhkan untuk melakukan transmisi data membutuhkan dari alat absensi ke server 100 milidetik.

TABEL I

WAKTU YANG DIPERLUKAN PADA PROSES ENROLL

\begin{tabular}{|c|c|c|c|c|}
\hline $\begin{array}{c}\text { NIM } \\
\text { Mahasiswa }\end{array}$ & $\begin{array}{c}\text { Waktu } \\
\text { Query } \\
\text { (detik) }\end{array}$ & $\begin{array}{c}\text { Waktu } \\
\text { pendaftaran } \\
\text { (detik) }\end{array}$ & $\begin{array}{c}\text { Waktu } \\
\text { update } \\
\text { (detik) }\end{array}$ & $\begin{array}{c}\text { Total } \\
\text { Waktu } \\
\text { (detik) }\end{array}$ \\
\hline 361855401001 & 0.005 & 4.2 & 0.092 & 4.297 \\
\hline 361855401002 & 0.003 & 3.5 & 0.100 & 3.603 \\
\hline 361855401003 & 0.003 & 4.1 & 0.113 & 4.216 \\
\hline 361855401004 & 0.003 & 3.7 & 0.092 & 3.795 \\
\hline 361855401005 & 0.003 & 4.2 & 0.097 & 4.3 \\
\hline 361855401006 & 0.003 & 3.8 & 0.102 & 3.905 \\
\hline 361855401007 & 0.005 & 3.8 & 0.097 & 3.902 \\
\hline
\end{tabular}

Posisi peletakan sidik jari pada lensa sensor fingerprint berpengaruh terhadap kecepatan waktu identifikasi karakter sidik jari. Pemberian tekanan jari pada lensa sensor mempercepat identifikasi karakter sidik jari oleh sensor fingerprint. Tabel 2 menampilkan waktu yang dibutuhkan sensor melakukan identifikasi karakter sidik jari. Meskipun semua jari dapat didentifikasi akan tetapi pada jari yang tidak ditekan waktu untuk identifikasi jauh lebih lama.

TABEL II

WAKTU IDENTIFIKASI KARAKTER SIDIK JARI

\begin{tabular}{|c|c|c|}
\hline Posisi Jari & $\begin{array}{c}\text { Keberhasilan } \\
(\mathbf{\%})\end{array}$ & $\begin{array}{c}\text { Waktu Identifikasi } \\
\text { (detik) }\end{array}$ \\
\hline ditekan & 100 & $3-4$ \\
\hline Tanpa ditekan & 100 & $6-8$ \\
\hline
\end{tabular}

Kegagalan pengambilan karakteristik sidik jari dikarenakan pada saat pendaftaran sidik jari mengalami perubahan posisi. Hal ini mengakibatkan data pada buffer 1 dan buffer 2 tidak sama. Tingkat kegagalan akibat posisi berubah pada saat pendaftaran sidik jari mencapai lebih 50\%, terlihat pada tabel 3 .

TABEL III

WAKTU IDENTIFIKASI KARAKTER SIDIK JARI

\begin{tabular}{|c|c|c|c|}
\hline Posisi Jari & $\begin{array}{c}\text { Pendaftaran } \\
\text { (orang) }\end{array}$ & $\begin{array}{c}\text { Berhasil } \\
\text { (orang) }\end{array}$ & $\begin{array}{c}\text { Gagal } \\
\text { (orang) }\end{array}$ \\
\hline Tetap & 30 & 30 & 0 \\
\hline Berubah & 30 & 14 & 16 \\
\hline
\end{tabular}

\section{3) Proses absensi}

Pelaksanaan absensi diawali oleh dosen yang mengajar mata kuliah sesuai jadwal, dilanjutkan dengan absensi mahasiswa yang mengikuti kegiatan perkuliahan. Identifikasi dosen untuk menentukan jadwal matakuliah dan kelas. Data kelas digunakan untuk mengambil data mahasiswa yang ada di database server untuk disimpan kedalam database lokal yang ada di Raspberry Pi. Penggunaan database lokal 
bertujuan untuk mengurangi kepadatan trafik transmisi paket data antara Raspberry Pi dengan server.

Gambar 15 menampilkan proses pengambilan data dari server untuk disimpan pada database lokal. Semua data yang dibutuhkan berhasil diambil dari server. Data yang diambil meliputi nama, NIM, kelas dan id fingerprint. Pada proses ini membutukan waktu $5 \mathrm{~ms}$.

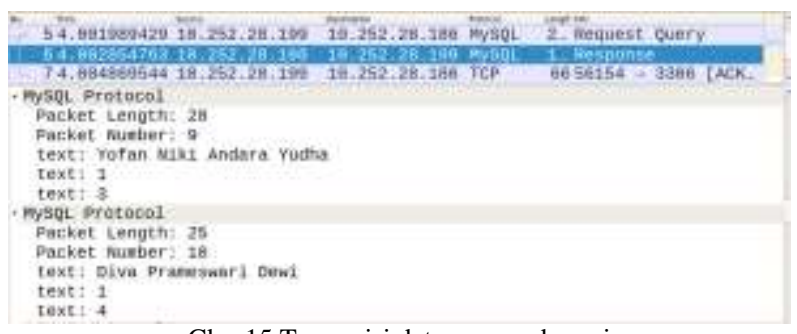

Gbr. 15 Transmisi data proses absensi

Pengujian absensi mahasiswa dilakukan dengan mengamati tingkat keberhasilan sensor fingerprint mengidentifikasi sidik jari tiap mahasiswa dan proses update data pada database lokal di Raspberry Pi. Semua mahasiswa berhasil melakukan absensi sebagai indikasi sidik jari yang sebelumnya direkam dapat dideteksi oleh sensor, terdapat beberapa mahasiswa yang harus melakukan absensi lebih dari 1 kali, karena sensor kesulitan melakukan identifikasi sidik jarinya. Prosentasi mahasiswa yang harus menggulang mencapai 13\%. Tabel IV menunjukan data beberapa mahasiswa yang harus mengulang pendeteksian sidik jari pada saat absensi.

TABEL IV

PENDETEKSIAN SIDIK JARI SAAT ABSENSI

\begin{tabular}{|c|c|c|c|}
\hline $\begin{array}{c}\text { Jumlah } \\
\text { Mahasiswa }\end{array}$ & $\begin{array}{c}\text { pendeksian } \\
\text { 1 kali }\end{array}$ & $\begin{array}{c}\text { pendeksian } \\
\text { 2 kali }\end{array}$ & $\begin{array}{c}\text { Waktu } \\
\text { deteksi } \\
\text { (detik) }\end{array}$ \\
\hline 29 & 25 & 4 & $2-4$ \\
\hline 30 & 28 & 2 & $2-3$ \\
\hline 30 & 29 & 3 & $2-3$ \\
\hline 31 & 29 & 3 & $2-3$ \\
\hline 31 & 30 & 1 & $2-3$ \\
\hline
\end{tabular}

Gambar 16 merupakan form absensi mahasiswa pada saat absensi. Mahasiswa yang berhasil melakukan pendeteksian sidik jari ditampilkannya NIM, nama dan kelas, sebaliknya jika data tersebut belum muncul maka mahasiswa harus melakukan pendeteksian sidik jari ulang.

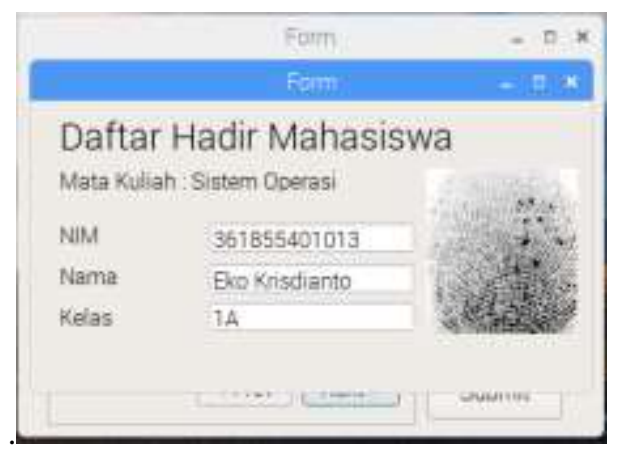

Gbr. 16 Absensi mahasiswa
Ketika semua mahasiswa sudah melakukan absensi maka dosen mengakhiri proses absensi dengan melakukan approvement. Sistem melakukan update database server berdasarkan data yang tersimpan pada database lokal Raspbbery. Hasil pengujian ditunjukan pada gambar 17. Alat absensi (client) mengirimkan request query pada server. Client menggunakan port 56142 dan server menggunakan port 3306. Paket data dikirim menggunakan protocol TCP. Selama proses pengujian data secara keseluruan dapat ditransmisikan dari client ke server dan koneksi jaringan wireless dalam kondisi stabil.

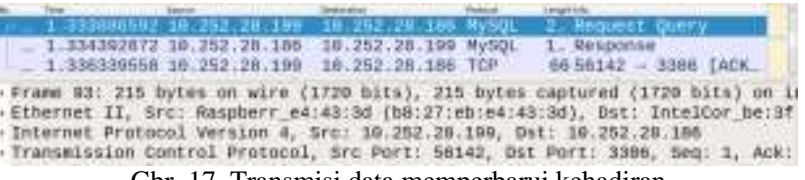

Gbr. 17 Transmisi data memperbarui kehadiran

\section{4) Laporan Absensi}

Hasil rekapitulasi kegiatan perkuliahan dapat dilihat pada halaman web. Penggunaan perintah SQL select untuk mengkases database berdasarkan NIM untuk mahasiswa dan NIP/NIK untuk dosen. Tampilan laporan absensi dapat dilihat pada gambar 18 .
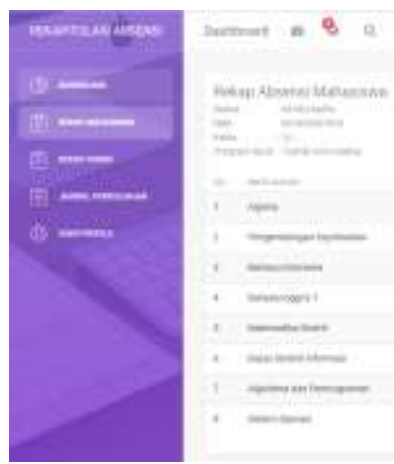

Gbr. 18 Rekap data absensi mahasiswa

\section{KESIMPULAN}

Penelitian menghasilkan sebuah alat absensi mahasiswa menggunakan sensor fingerprint sebagai otentikasi. data kegiatan perkuliahan disimpan dalam database server. Transmisi data antara alat absensi dan server menggunakan jaringan wireless lokal. Proses absensi menggunakan sidik jari diawali dengan melakukan proses enroll (pendaftaran) sidik jari pada alat absensi menggunakan sensor fingerprint. Proses enroll dipengaruhi oleh waktu query, identifikasi sidik jari dan update database. Waktu yang dibutuhkan melakukan enroll sekitar 5 detik per orang. Proses enroll dapat mengalami kegagalan apabila terjadi perubahan posisi jari pada saat enroll. Absensi mahasiswa dilakukan dengan mengambil data mahasiswa yang tersimpan pada database server berdasarkan kelas sesuai jadwal perkuliahan. Data tersebut disimpan sementara dalam database lokal yang ada di Raspberry Pi. Prosentasi keberhasilan identifikasi sensor fingerprint terhadap sidik jari mahasiswa pada saat melakukan absensi mencapai $100 \%$ dengan waktu rata-rata 3 detik.

Transmisi data antara alat absensi dan server menggunakan jaringan wireless berhasil dilakukan. Koneksi 
dalam kondisi stabil dengan jarak yang memenuhi kebutuhan sistem. Transmisi menggunakan protocol TCP memberikan jaminan paket data dapat diterima secara utuh oleh sistem. Sistem absensi mahasiswa menggunakan sensor fingerprint dapat dikembangkan lagi untuk mengatasi jumlah kapasitas penyimpanan template sidik jari pada perangkat sensor fingerprint. Kapasitas yang disediakan sensor fingerprint hanya 1000 template. Convert template data karekatristik sidik jari kedalam tipe data tertentu untuk dapat disimpan dalam database server, meski dapat mengakibatkan besarnya kapaitas data yang ditransmisikan ke server. Hal dapat mengatasi permasalahan kapasitas minimnya storage yang disedikan sensor fingerprint untuk menyimpan template fingerprint.

\section{UCAPAN TERIMA KASIH}

Ucapan terima kasih kepada Pimpinan Politeknik Negeri Banyuwangi yang telah membantu pendanaan kegiatan penelitian melalui Pusat Penelitian dan Pengabdian kepada Masyarakat (P3M). Terima kasih pada Ketua jurusan dan Ketua Laboratorium Program Studi Teknik Informatika Politeknik Negeri Banyuwangi.

\section{DAFTAR PUSTAKA}

[1] W.I Nuriman, D. Darlis, dan D.A. Nurmantris, "Implementasi Sistem Informasi Kuliner pada Angkutan Publik berbasis Single Board Computer". Jurnal Informatika:Jurnal Pengembangan IT (JPIT),vol. 02, no.02,pp .9-13, 2017.

[2] Muhammad Yusuf, R. V. Hari Ginardi, dan Adhatus Solichah A,"Rancang Bangun Aplikasi Absensi Perkuliahan Mahasiswa dengan Pengenalan Wajah", JURNAL TEKNIK ITS, Vol. 5, No. 2, pp. A766A770, (2016)
[3] Vishal Suryawanshi, Kiran Puri, Prashant Devkar, dan K.S.Tiwari. "Attendance Monitoring System Automation Using Fingerprint Module". International Journal of Electrical, Electronics and Computer Systems (IJEECS). Vol.6, No.1, pp. 44-47, 2017.

[4] Joyner R. Oroh, Elia Kendekallo, Sherwin R. U. A. Sompie dan Janny O. Wuwung, "Rancang Bangun Sistem Keamanan Motor Dengan Pengenalan Sidik Jari”, e-Journal Teknik Elektro dan Komputer, pp. $1-7,2014$.

[5] Gat. "Integrasi Fingerprint System Dengan Real Time Absensi Dosen Berbasis Web (Studi Kasus : STMIK Pontianak)". Cogito Smart Journal, Vol. 2, No. 2, pp. 135-146, 2016.

[6] Shahzad Memon, Mojtaba Sepasian dan Wamadeva Balachandran, "Review of finger print sensing technologies", IEEE International Multitopic Conference, 2008, pp. 226-231.

[7] Aarushi Jalundhwala, Pratik Jhaveri, Sandeep Khudanpur dan Amit Deshmukh. 2014. Wireless Fingerprint Attendance Marking System. International Journal of Computer Applications.108(8):1-5

[8] Yongqiang Zhang dan Ji Liu, "Wireless Fingerprint Attendance Management System". International Conference on Computer Engineering and Applications. 17-19 Januari 2007, pp.451-455

[9] J.Chandramohan,R.Nagarajan, M. Ashok kumar, T.Dineshkumar dan G.Kannan, "Attendance Monitoring System of Students Based on Biometric and GPS Tracking System", International Journal of Advanced Engineering, Management and Science (IJAEMS), Vol3, No.3, pp. 241-246, 2017.

[10] Jordi Sapes dan Francesc Solsona, "FingerScanner: Embedding a Fingerprint Scanner in a Raspberry Pi”, Sensors,Vol.16, No. 220, p.1$18,2016$.

[11] Nareshkumar R. M.,Apoorva Kamat, dan Dnyaneshvari Shinde, " Smart Door Security Control System Using Raspberry Pi", International Journal of Innovations \& Advancement in Computer Science (IJIACS), Vol, 6, No. 11, pp. 499-503, 2017.

[12] Akash V. Bhatkule, Ulhas B. Shinde,dan Shrinivas R. Zanwar, "Home Based Security Control System using Raspberry Pi and GSM", International Journal of Innovative Research in Computer and Communication Engineering, Vol. 4, No. 9, pp.16259-16264, 2016.

[13] R.N.Dasmen, "Implementasi Raspberry Pi 3 Sebagai Wireless Access Point Pada STIPER Sriwigama Palembang". Jurnal Informatika: Jurnal Pengembangan IT (JPIT), Vol.03, No.03, pp. 387-393,2018 